\title{
A Festschrift in honor of Professor Adam Boratyński - forester, botanist, and traveller
}

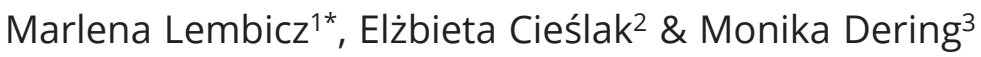

Professor Adam Boratyński is a forester and botanist by education. He graduated from the Faculty of Forestry at the Poznań University of Life Sciences (previously, the August Cieszkowski Agricultural University of Poznań). Presently, he is a senior professor, very active as a researcher and educator and with great organizational skills. He is also an author and co-author of many scientific articles, monographs, atlases and chapters in the books that are of significant importance for the world's scientific literature. Trees and shrubs in the scientific life of Professor Boratynski are the focus of his research. The professor, apart from scientific articles, is the author of monographic studies of various tree species in the encyclopedia 'Enzyclopädie der Holzgewächse'.

Professor Boratyński is a friend of many botanists, especially young people. He always has time for conversations with them about science and life in general and is very interested in their problems, both scientific and connected with everyday life. He inspires young people to create different alternative hypotheses and search for and use various tools and technologies to solve research problems. Professor Boratyński has been continually developing his research techniques. He is one of the first Polish botanists to apply genetic analyses to solve phytogeographical problems and formed a team of young people, who presently develop high level research in the area of phylogeography, based on molecular techniques.

Professor Boratyński is also a passionate traveller, who uses travels for nature observation and collecting material for studies in plant systematics, chorology and ecology. Among Professor's favourite research regions are the Mediterranean Basin and Sudeten Mountains (Figs 1-2). The Mediterranean Sea (mediterraneus from Latin - inland or in the middle of the land) significantly affects the climate and vegetation of surrounding areas. It is vegetation of this region, particularly the dendroflora of Greece, Spain and some Mediterranean islands, which has been in the center of Professor's scientific interests.

\footnotetext{
${ }^{1}$ Adam Mickiewicz University, Faculty of Biology, Department of Systematic and Environmental Botany, Poznań, Poland

${ }^{2}$ W. Szafer Institute of Botany, Polish Academy of Sciences, Lubicz 46, 51-312 Kraków, Poland

${ }^{3}$ Poznań University of Life Sciences, Department of Silviculture, Wojska Polskiego 71a, 60-625 Poznań, Poland

* Corresponding author e-mail: lembicz@amu.edu.pl
}

In this place, it is worth recalling the work on dendroflora of Greece or the monograph of Empetraceae on the Iberian Peninsula, written in cooperation with his Spanish colleagues from the Botanical Institute of Barcelona. The Sudetes are the second special place for Professor Boratyński. The dendroflora of Karkonosze Mountains, the highest range of the Sudetes, was the study object of his habilitation thesis. No doubt, the biology and ecology of common yew (Taxus baccata) and many other trees were investigated in depth thanks to the Professor's research.

The current issue of the journal Plant and Fungus Systematics is dedicated to Professor Adam Boratyński. On behalf of the journal's editors and Polish botanists, we wish to thank Professor Boratyński for his passionate research work, for all past and future discussions about nature and science and, above all, for his great kindness for people and peacefulness - both features so rarely met nowadays.

We thank all the authors for their contributions to this issue, which is published to express our heartfelt appreciation of Professor Adam Boratyński.

You will find information about the scientific works of Prof. Boratyński: https://orcid.org/0000-0003-0678-4304; https://www.researchgate.net/profile/Adam-Boratynski.

\section{Some publications by Adam Boratyński}

Boratyński, A. \& Browicz, K. 1976. In: Browicz, K. (ed.) Atlas rozmieszczenia drzew i krzewów w Polsce. 17. PWN, Warszawa-Poznań.

Boratyńska, K. \& Boratyński, A. 1976. In: Browicz, K. (ed.) Atlas rozmieszczenia drzew i krzewów w Polsce. 19. PWN, Warszawa-Poznań.

Boratyńska, K. \& Boratyński, A. 1977. In: Browicz, K. (ed.) Atlas rozmieszczenia drzew i krzewów w Polsce. 23. PWN, Warszawa-Poznań.

Boratyńska, K. \& Boratyński, A. 1978. In: Browicz, K. (ed.) Atlas rozmieszczenia drzew i krzewów w Polsce. 25. PWN, Warszawa-Poznań.

Boratyńska, K. \& Boratyński, A. 1979. In: Browicz, K. (ed.) Atlas rozmieszczenia drzew i krzewów w Polsce. 27. PWN, Warszawa-Poznań.

Boratyńska, K., Boratyński, A. \& Hantz, J. 1980. In: Browicz, K. (ed.) Atlas rozmieszczenia drzew i krzewów w Polsce. 30. PWN, Warszawa-Poznań. 

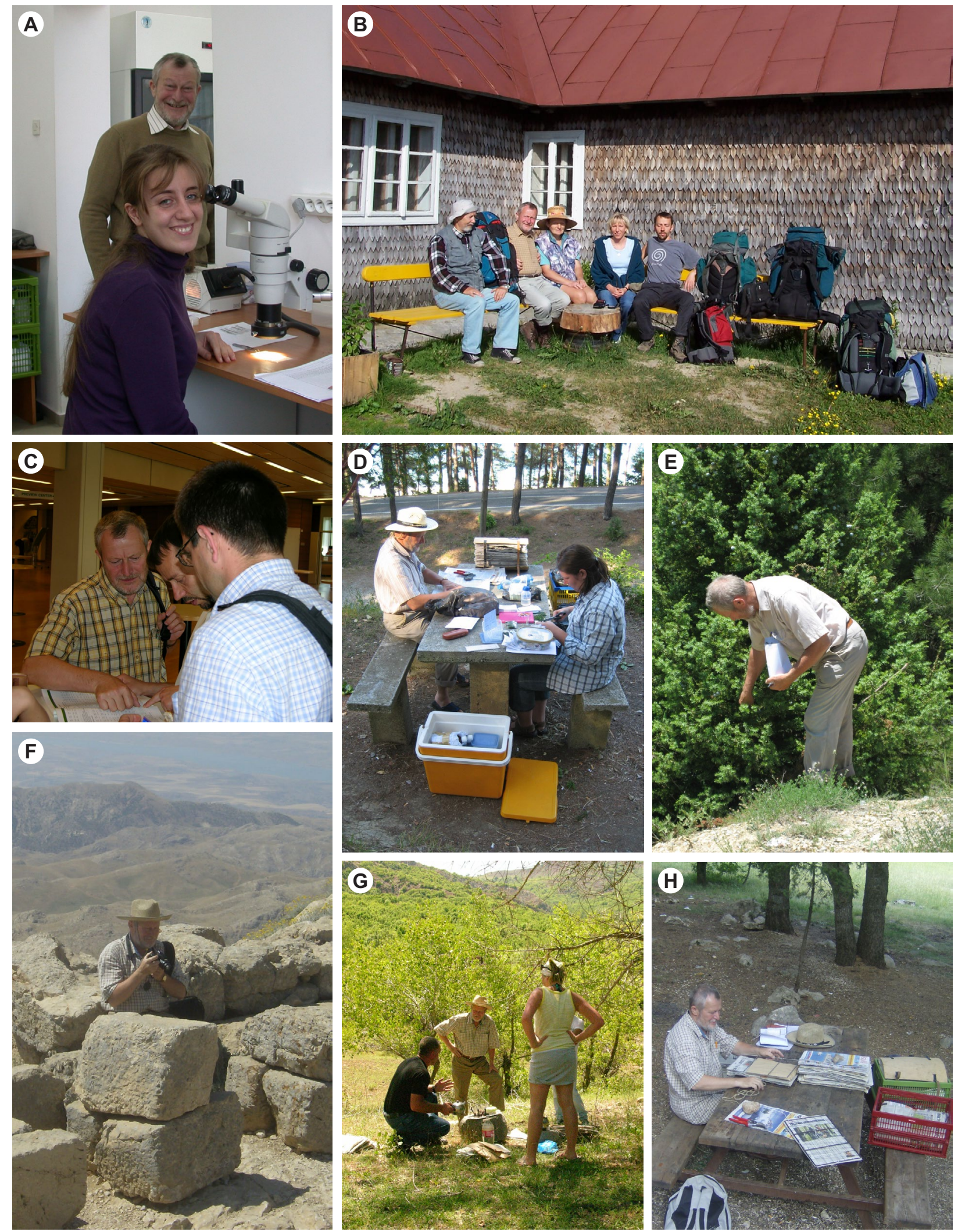

Figure 1. A - Adam Boratyński with Bouchra Douaihy, Kórnik, Poland (2011); B - Adam Boratyński with Yakiv Didukh, Barbara Waldon-Rudzionek, Piotr Kosiński, expedition to Ukraine (2004); C - Adam Boratyński with Dominik Tomaszewski during International Botanical Congress, IBC, Vienna, Austria (2005); D - Adam Boratyński with Anna K. Jasińska, expedition to Turkey (2005); E - Adam Boratyński, expedition to Turkey (2005); F - Adam Boratyński, expedition to Turkey (2009); G - Adam Boratyński with Karolina Sobierajska, expedition to Turkey (2009); H Adam Boratyński, expedition to Turkey (2009). Photos: archives of the expedition team. 

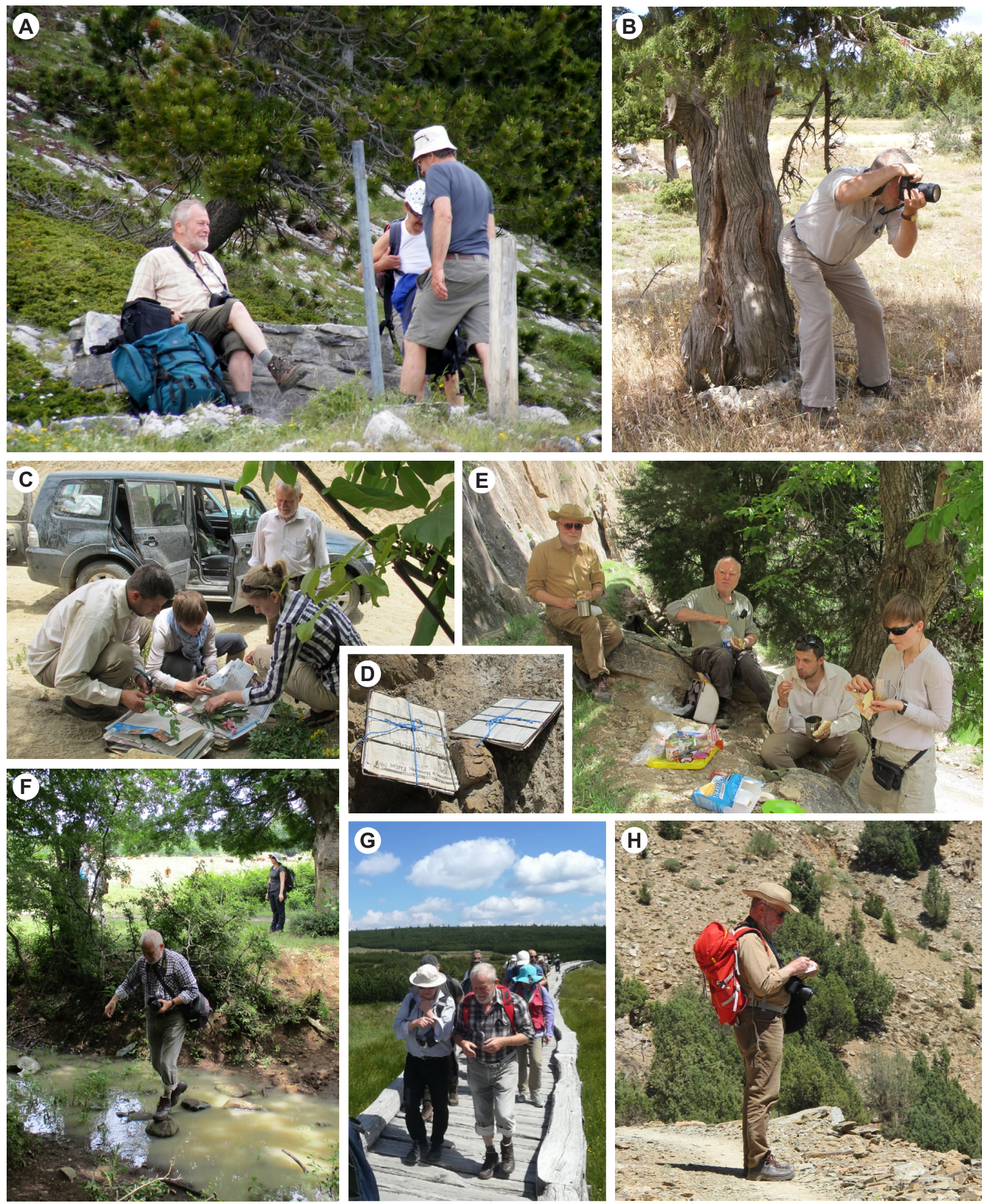

Figure 2. A - Adam Boratyński with the participants of the expedition to Greece and Bulgaria (2010); B - Adam Boratyński, expedition to Greece (2010); C - Adam Boratyński with Maciej Sękiewicz, Monika Dering, Katarzyna Sękiewicz, expedition to Morocco (2014); D - Drying in herbarium nets collecting plant material during the expedition to Morocco (2014); E - Adam Boratyński with Pedro Soria Estevan, Maciej Sękiewicz, Monika Dering, expedition to Morocco (2014); F - Adam Boratyński, expedition to Georgia (2017); G - Adam Boratyński as a guide, Karkonosze, Poland (2017); H - Adam Boratyński, expedition to Morocco (2014). Photos: archives of the expedition team. 
Boratyńska, K., Boratyński, A., Browicz, K. \& Hantz, J. 1981. In: Browicz, K. (ed.) Atlas rozmieszczenia drzew i krzewów w Polsce. 31. PWN, Warszawa-Poznań.

Boratyński, A. 1985. Rzadkie i godne ochrony drzewa i krzewy polskiej części Sudetów, Pogórza i Przedgórza Sudeckiego. 1. Juniperus communis L. s.lat. Arboretum Kórnickie 30: 111-126.

Boratyński, A. 1986. Chronione i godne ochrony drzewa i krzewy polskiej części Sudetów, Pogórza i Przedgórza Sudeckiego. 2. Empetrum nigrum L. s.lat. Arboretum Kórnickie 31: 21-37.

Boratyński, A. \& Danielewicz, W. 1989. Chronione i godne ochrony drzewa i krzewy polskiej części Sudetów, Pogórza i Przedgórza Sudeckiego. 5. Betula pubescens Ehr. subsp. carpatica (Waldst. et Kit.) Asch. et Graebner. Arboretum Kórnickie 34: 71-88.

Boratyński, A., Konca, B. \& Zientarski, J. 1989. An instance of the most endangered forest association in the mountains of central Europe. Pirineos 133: 3-32.

Boratyńska, K. \& Boratyński, A. 1990. Systematyka i geograficzne rozmieszczenie. In: Buk zwyczajny Fagus sylvatica L. Białobok S. (ed.). Nasze Drzewa Leśne 10: 27-73.

Boratyński, A. 1991. Chorologiczna analiza flory drzew i krzewów Sudetów Zachodnich. 323 pp. Polska Akademia Nauk, Instytut Dendrologii, Kórnik.

Boratyński, A. 1991. Range of natural distribution. Developments in plant genetics and breeding 3 (C): 19-30.

Boratyński, A., Browicz, K. \& Zieliński, J. 1992. Chorology of Trees and Shrubs in Greece. 286 pp. + 24 maps. Polish Academy of Sciences. Institute of Dendrology, Sorus, Poznań-Kórnik.

Białobok, S., Boratyński, A. \& Bugała W. (ed.) 1993. Biologia sosny zwyczajnej. 624 pp. Polska Akademia Nauk, Instytut Dendrologii, Sorus, Poznań-Kórnik.

Boratyński, A. \& De La Puente, M. L. V. 1995. The Empetraceae on the Iberian Peninsula. Willdenowia 25(1): 39-53.

Boratyński, A., Kosiński, P., Kwiatkowski, P. \& Szlachetka, A. 1995. Chronione i godne ochrony drzewa i krzewy polskiej części Sudetów, Pogórza i Przedgórza Sudeckiego. 8. Sorbus torminalis (L.) Crantz. Arboretum Kórnickie 40: 11-35.

Lewandowski, A., Boratyński, A. \& Mejnartowicz, L. 1996. Low level of isoenzyme variation in an island population of Juniperus oxycedrus subsp. macrocarpa (Sm. Ex Sibth.) Ball. Acta Societatis Botanicorum Poloniae 65(3-4): 335-338.

Boratyński, A., Kmiecik, M., Kosiński, P., Kwiatkowski, P. \& Szczęśniak, E. 1997. Chronione i godne ochrony drzewa i krzewy polskiej części Sudetów, Pogórza i Przedgórza Sudeckiego. 9. Taxus baccata L. Arboretum Kórnickie 42: 111-147.

Boratyński A. \& Bugała W. 1998. (eds). Biologia świerka pospolitego. 781 pp. +32 tabl. Polska Akademia Nauk, Instytut Dendrologii, Bogucki Wydawnictwo Naukowe, Poznań.

Boratyński, A. 1994. Chronione i godne ochrony drzewa i krzewy polskiej części Sudetów, Pogórza i Przedgórza Sudeckiego. 7. Pinus mugo Turra i Pinus uliginosa Neumann. Arboretum Kórnickie 39: 63-85.

Boratyński, A., Kosiński, P., Kwiatkowski, P., Szczęśniak, E. \& Świerkosz, K. 1999. Chronione i godne ochrony drzewa i krzewy polskiej części Sudetów, Pogórza i Przedgórza
Sudeckiego. 5. Cotoneaster integerrimus Medik. i C. niger (Thunb.) Fr. Arboretum Kórnickie 44: 5-22.

Lewandowski, A., Boratyński, A. \& Mejnartowicz, L. 2000. Allozyme investigations on the genetic differentiation between closely related pines Pinus sylvestris, P. mugo, P. uncinata, and P. uliginosa (Pinaceae). Plant Systematics and Evolution 221(1-2): 15-24.

Boratyński, A., Didukh, Y. \& Lucak, M. 2001. The yew (Taxus baccata L.) population in Knyazhdvir: Nature Reserve in the Carpathians (Ukraine). Dendrobiology 46: 3-8.

Boratyńska, K., Boratyński, A. \& Lewandowski, A. 2003. Morphology of Pinus uliginosa (Pinaceae) needles from populations exposed to and isolated from the direct influence of Pinus sylvestris. Botanical Journal of the Linnean Society 142(1): 83-91.

Boratyński, A., Boratyńska, K., Lewandowski, A., Gołạb, Z. $\&$ Kiciński, P. 2003. Evidence of the possibility of natural reciprocal crosses between Pinus sylvestris and P. uliginosa based on the phenology of reproductive organs. Flora: Morphology, Distribution, Functional Ecology of Plants 198(5): 377-388.

Mazur, M., Boratyńska, K., Marcysiak, K., Gómez, D., Tomaszewski, D., Didukh, Y. \& Boratyński, A. 2003. Morphological variability of Juniperus phoenicea (Cupressaceae) from three distant localities on Iberian Peninsula. Acta Societatis Botanicorum Poloniae 72(1): 71-78.

Boratyński, A. \& Romo, A. 2003. Loiseleuria procumbens (Ericaceae) in the Spanish Pyrenees. Acta Societatis Botanicorum Poloniae 72(2): 125-133.

Romo, A., Didukh, Y. \& Boratyński, A. 2004. Thesium (Santalaceae) in Crimea, Ukraine. Annales Botanici Fennici 41(4): 273-281.

Boratyńska, K., Marcysiak, K. \& Boratyński, A. 2005. Pinus mugo (Pinaceae) in the Abruzzi Mountains: High morphological variation in isolated populations. Botanical Journal of the Linnean Society 147(3): 309-316.

Iszkuło, G. \& Boratyński, A. 2005. Different age and spatial structure of two spontaneous subpopulations of Taxus baccata as a result of various intensity of colonization process. Flora: Morphology, Distribution, Functional Ecology of Plants 200(2): 195-206.

Boratyńska, K. \& Boratyński, A. 2006. Occurrence of three-needle dwarf shoots on European species of the genus Pinus (Pinaceae). Plant Biosystems 140(1): 21-26.

Boratyński, A., Piwczyński, M., Didukh, Y., Tasenkevich, L., Romo, A. \& Ratyńska, H. 2006. Distribution and phytocoenotic characteristics of relict populations of Rhododendron myrtifolium (Ericaceae) in the Ukrainian Carpathians. Polish Botanical Studies 22: 53-62.

Klimko, M., Boratyńska, K., Montserrat, J. M., Didukh, Y., Romo, A., Gómez, D., Kluza-Wieloch, M., Marcysiak, K. \& Boratyński, A. 2007. Morphological variation of Juniperus oxycedrus subsp. oxycedrus (Cupressaceae) in the Mediterranean region. Flora: Morphology, Distribution, Functional Ecology of Plants 202(2): 133-147.

Marcysiak, K. \& Boratyński, A. 2007. Contribution to the taxonomy of Pinus uncinata (Pinaceae) based on cone characters. Plant Systematics and Evolution 264(1-2): 57-73.

Marcysiak, K., Mazur, M., Romo, A., Montserrat, J. M., Didukh, Y., Boratyńska, K., Jasińska, A., Kosiński, P. \& Boratyński, A. 2007. Numerical taxonomy of Juniperus thurifera, 
J. excelsa and J. foetidissima (Cupressaceae) based on morphological characters. Botanical Journal of the Linnean Society 155(4): 483-495.

Romo, A. \& Boratyński, A. 2007. Notes and contributions to the vascular flora of Oukaïmeden (Central High Atlas, Morocco). Candollea 62(1): 69-89.

Boratyński, A., Marcysiak, K., Lewandowska, A., Jasińska, A. K., Iszkulo, G. \& Burczyk, J. 2008. Differences in leaf morphology between Quercus petraea and Q. robur adult and young individuals. Silva Fennica 42(1): 115-124.

Boratyński, A., Lewandowski, A., Boratyńska, K., Montserrat, J. M. \& Romo, A. 2009. High level of genetic differentiation of Juniperus phoenicea (Cupressaceae) in the Mediterranean region: geographic implications. Plant Systematics and Evolution 277(3-4): 163-172.

Dzialuk, A., Muchewicz, E., Boratyński, A., Montserrat, J. M., Boratyńska, K. \& Burczyk, J. 2009. Genetic variation of Pinus uncinata (Pinaceae) in the Pyrenees determined with cpSSR markers. Plant Systematics and Evolution 277(3-4): 197-205.

Iszkuło, G., Jasińska, A. K., Giertych, M. J. \& Boratyński, A. 2009. Do secondary sexual dimorphism and female intolerance to drought influence the sex ratio and extinction risk of Taxus baccata? Plant Ecology 200(2): 229-240.

Jasińska, A. K., Wachowiak, W., Muchewicz, E., Boratyńska, K., Montserrat, J. M. \& Boratyński, A. 2010. Cryptic hybrids between Pinus uncinata and P. sylvestris. Botanical Journal of the Linnean Society 163(4): 473-485.

Douaihy, B., Vendramin, G. G., Boratyński, A., Machon, N. \& Dagher-Kharrat, M. B. 2011. High genetic diversity with moderate differentiation in Juniperus excelsa from Lebanon and the eastern Mediterranean region. AoB PLANTS 11(1): plr003.

Dzialuk, A., Mazur, M., Boratyńska, K., Montserrat, J. M., Romo, A. \& Boratyński, A. 2011. Population genetic structure of Juniperus phoenicea (Cupressaceae) in the western mediterranean basin: Gradient of diversity on a broad geographical scale. Annals of Forest Science 68(8): 1341-1350.

Iszkuło, G. \& Boratyński, A. 2011. Initial period of sexual maturity determines the greater growth rate of male over female in the dioecious tree Juniperus communis subsp. communis. Acta Oecologica 37(2): 99-102.

Jasińska, A. K., Boratyńska, K., Sobierajska, K., Romo, A. M., Ok, T., Kharat, M. B. D. \& Boratyński, A. 2013. Relationships among Cedrus libani, C. brevifolia and C. atlantica as revealed by the morphological and anatomical needle characters. Plant Systematics and Evolution 299(1): 35-48.

Romo, A., Hidalgo, O., Boratyński, A., Sobierajska, K., Jasińska, A. K., Vallès, J. \& Garnatje, T. 2013. Genome size and ploidy levels in highly fragmented habitats: The case of western Mediterranean Juniperus (Cupressaceae) with special emphasis on J. thurifera L. Tree Genetics and Genomes 9(2): 587-599.

Sękiewicz, K., Sękiewicz, M., Jasińska, A. K., Boratyńska, K., Iszkuło, G., Romo, A. \& Boratyński, A. 2013. Morphological diversity and structure of West Mediterranean Abies species. Plant Biosystems 147: 125-134.

Boratyński, A., Wachowiak, W., Dering, M., Boratyńska, K., Sękiewicz, K., Sobierajska, K., Jasińska, A. K., Klimko, M., Montserrat, J. M., Romo, A., Ok, T. \& Didukh, Y. 2014. The biogeography and genetic relationships of Juniperus oxycedrus and related taxa from the Mediterranean and Macaronesian regions. Botanical Journal of the Linnean Society 174: 637-653.

Dering, M., Sękiewicz, K., Boratyńska, K., Litkowiec, M., Iszkuło, G., Romo, A. \& Boratyński, A. 2014. Genetic diversity and inter-specific relations of western Mediterranean relic Abies taxa as compared to the Iberian A. alba. Flora: Morphology, Distribution, Functional Ecology of Plants 209(7): 367-374.

Jasińska, A. K., Boratyńska, K., Dering, M., Sobierajska, K. I., Ok, T., Romo, A. \& Boratyński, A. 2014. Distance between south-European and south-west Asiatic refugial areas involved morphological differentiation: Pinus sylvestris case study. Plant Systematics and Evolution 300: 1487-1502.

Romo, A. \& Boratyński, A. 2014. The genus Cotoneaster (Rosaceae) in NW Africa. Willdenowia 44(2): 229-239.

Boratyńska, K., Jasińska, A. K. \& Boratyński, A. 2015. Taxonomic and geographic differentiation of Pinus mugo complex on the needle characteristics. Systematics and Biodiversity 13(6): 901-915.

Jasińska, A. K., Rucińska, B., Kozlowski, G., Bétrisey, S., Safarov, H., Boratyńska, K. \& Boratyński, A. 2015. Morphological differentiation of leaves in the relict tree Zelkova carpinifolia (Ulmaceae). Dendrobiology 74: 109-122.

Sękiewicz, K., Dering, M., Sękiewicz, M., Boratyńska, K., Iszkuło, G., Litkowiec, M., Ok, T., Dagher-Kharrat, M. B. \& Boratyński, A. 2015. Effect of geographic range discontinuity on species differentiation East-Mediterranean Abies cilicica: a case study. Tree Genetics and Genomes 11(1): 10.

Mazur, M., Minissale, P., Sciandrello, S. \& Boratyński, A. 2016. Morphological and ecological comparison of populations of Juniperus turbinata Guss. and J. phoenicea L. from the Mediterranean region. Plant Biosystems 150(2): 313-322.

Sękiewicz, K., Boratyńska, K., Dagher-Kharrat, M. B., Ok, T. \& Boratyński, A. 2016. Taxonomic differentiation of $\mathrm{Cu}$ pressus sempervirens and C. atlantica based on morphometric evidence. Systematics and Biodiversity 14(5): 494-508.

Sobierajska, K., Boratyńska, K., Jasińska, A., Dering, M., Ok, T., Douaihy, B., Bou Dagher-Kharrat, M., Romo, Á. \& Boratyński, A. 2016. Effect of the Aegean Sea barrier between Europe and Asia on differentiation in Juniperus drupacea (Cupressaceae). Botanical Journal of the Linnean Society 180(3): 365-385.

Dering, M., Kosiński, P., Wyka, T. P., Pers-Kamczyc, E., Boratyński, A., Boratyńska, K., Reich, P. B., Romo, A., Zadworny, M., Żytkowiak, R. \& Oleksyn, J. 2017. Tertiary remnants and holocene colonizers: Genetic structure and phylogeography of Scots pine reveal higher genetic diversity in young boreal than in relict Mediterranean populations and a dual colonization of Fennoscandia. Diversity and Distributions 23(5): 540-555.

Dzialuk, A., Boratyńska, K., Romo, A. \& Boratyński, A. 2017. Taxonomic and geographic variation of the Pinus mugo complex on chloroplast microsatellite markers. Systematics and Biodiversity 15(5): 464-479.

Jasińska, A., Boratyńska, K., Sękiewicz, K., Di Gristina, E. \& Boratyński, A. 2017. Relationships among Abies nebrodensis, A. alba and A. cephalonica in the morphological and anatomical needle characteristics. Plant Biosystems 151(5): 775-782. 
Jasińska, A., Sękiewicz, K., Ok, T., Romo, A., Boratyński, A. \& Boratyńska, K. 2017. Taxonomic position of Abies equi-trojani on the basis of needle characters by comparison with different fir species. Turkish Journal of Botany 41(6): 620-631.

Romo, A., Iszkuło, G., Seghir Taleb, M., Walas, Ł. \& Boratyński, A. 2017. Taxus baccata in Morocco: A tree in regression in its southern extreme. Dendrobiology 78: 63-74.

Didukh Y., Kontar I. \& Boratyński A. 2018. Phytoindicating Comparison of Vegetation of the Polish Tatras, the Ukrainian Carpathians and the Mountain Crimea. In: Greller A., Fujiwara K. \& Pedrotti F. (eds) Geographical Changes in Vegetation and Plant Functional Types. Geobotany Studies (Basics, Methods and Case Studies). Springer, Cham. https:// doi.org/10.1007/978-3-319-68738-4_9

Mazur, M., Zielińska, M., Boratyńska, K., Romo, A., SalvàCatarineu, M., Marcysiak, K. \& Boratyński, A. 2018. Taxonomic and geographic differentiation of Juniperus phoenicea agg. based on cone, seed, and needle characteristics. Systematics and Biodiversity 16(5): 469-482.

Sẹkiewicz, K., Dering, M., Romo, A., Dagher-Kharrat, M. B., Boratyńska, K., Ok, T. \& Boratyński, A. 2018. Phylogenetic and biogeographic insights into long-lived Mediterranean Cupressus taxa with a schizo-endemic distribution and Tertiary origin. Botanical Journal of the Linnean Society 188(2): 190-212.

Kosiński, P., Sękiewicz, K., Walas, Ł., Boratyński, A. \& Dering, M. 2019. Spatial genetic structure of the endemic alpine plant Salix serpillifolia: genetic swamping on nunataks due to secondary colonization? Alpine Botany 129(2): 107-121.

Kosiński, P., Sliwinska, E., Hilpold, A. \& Boratyński, A. 2019. DNA ploidy in Salix retusa agg. only partly in line with its morphology and taxonomy. Nordic Journal of Botany 37(7): e02197.

Romo, A., Mazur, M., Salvà-Catarineu, M. \& Boratyński, A. 2019. A re-evaluated taxon: Genetic values and morphological characters support the recognition of the Canary Island juniper of the phoenicea group at a specific level. Phytotaxa 406(1): 64-70.

Walas, Ł., Sobierajska, K., Ok, T., Dönmez, A. A., Kanoğlu, S. S., Dagher-Kharrat, M. B., Douaihy, B., Romo, A.,
Stephan, J., Jasińska, A. K. \& Boratyński, A. 2019. Past, present, and future geographic range of an oro-Mediterranean Tertiary relict: the Juniperus drupacea case study. Regional Environmental Change 19(5): 1507-1520.

Litkowiec, M., Sękiewicz, K., Romo, A., Ok, T., Bou Dagher-Kharrat, M., Jasińska, A. K., Sobierajska, K., Boratyńska, K. \& Boratyński, A. 2021. Biogeography and relationships of the Abies taxa from the mediterranean and central Europe regions as revealed by nuclear DNA markers and needle structural characters. Forest Ecology and Management 479: 118606.

Sobierajska, K., Wachowiak, W., Zaborowska, J., Łabiszak, B., Wójkiewicz, B., Sękiewicz, M., Jasińska, A. K., Sękiewicz, K., Boratyńska, K., Marcysiak, K. \& Boratyński, A. 2020. Genetic consequences of hybridization in relict isolated trees Pinus sylvestris and the Pinus mugo complex. Forests 11: 1086.

Taib, A., Morsli, A., Chojnacka, A., Walas, Ł., Sękiewicz, K., Boratyński, A., Romo, A. \& Dering, M. 2020. Patterns of genetic diversity in North Africa: Moroccan-Algerian genetic split in Juniperus thurifera subsp. africana. Scientific Reports 10: 4810.

Mazur, M., Boratyński, A., Boratyńska, K. \& Marcysiak, K. 2021. Weak geographical structure of Juniperus sabina (Cupressaceae) morphology despite its discontinuous range and genetic differentiation. Diversity 13(10), 470, https://doi. org $/ 10.3390 / \mathrm{d} 13100470$

Salvà-Catarineu, M., Romo, A., Mazur, M., Zielińska, M., Minissale, P., Dönmez, A. A., Boratyńska, K. \& Boratyński, A. 2021. Past, present and future geographic range of the relict Mediterranean and Macaronesian Juniperus phoenicea complex. Ecology and Evolution 11(10): 5075-5095.

Song, Y. G., Walas, Ł., Pietras, M., Sâm, H. V., Yousefzadeh, H., Ok, T., Farzaliyev, V., Worobiec, G., Worobiec, E., Stachowicz-Rybka, R., Boratyński, A., Boratyńska, K., Kozlowski, G. \& Jasińska, A. K. 2021. Past, present and future suitable areas for the relict tree Pterocarya fraxinifolia (Juglandaceae): Integrating fossil records, niche modeling, and phylogeography for conservation. European Journal of Forest Research 140(6): 1323-1339. 